\title{
The mitigation of CO2 Emission in the Sea Water Desalination Plant with Reverse Electrodialysis Power Generation
}

\author{
Suka Handaja ${ }^{1 *}$, Heru Susanto ${ }^{2}$, Hermawan $^{3}$ \\ ${ }^{1}$ Politeknik Energi dan Mineral [PEM] Akamigas, Jln. Gadjah Mada No. 38, Cepu 58315 \\ ${ }^{2}$ Chemical Engineering Department, Diponegoro University, Indonesia \\ 3 Electrical Engineering Department, Diponegoro University, Indonesia
}

\begin{abstract}
Climate change is a major issue that is very interesting to discuss. Climate change is believed to be caused by the greenhouse gas effect. $\mathrm{CO}_{2}$ is one of the gases that causes the greenhouse gas effect. Therefore, to avoid the dangers of climate change, reducing $\mathrm{CO}_{2}$ emissions is the main topic in various articles. In this article, $\mathrm{CO}_{2}$ emission mitigation is analyzed in the sea water desalination plant using reverse electrodialysis power generation. Reverse electrodialysis is a power plant that does not produce $\mathrm{CO}_{2}$ emissions which converts energy from the difference in salinity of two solutions into electrical energy through selective ion membrane technology. There are 8 sea water desalination (SWD) unit which produces 242 tons/h of clean water for industrial activity and blowdown water of 3,161 tons/h, the blowdown water is wastewater. The SWD unit requires 3.043 tons/h of seawater as feed water, $0.164 \mathrm{MW}$ of electricity and 86 tons/h of steam worth 64.1 MW as an energy. The energy are met from the combined heat and power operation. Combined heat and power require of fuel oil and fuel gas which produce $\mathrm{CO}_{2}$ emissions of $1,352,445,626 \mathrm{kgCO}_{2} / \mathrm{y}$. From the analysis on the SWD plant, the $\mathrm{CO}_{2}$ emission is $148,411,874$ $\mathrm{kgCO}_{2} / \mathrm{y}$. By implementing reverse electrodialysis power generation, blowdown water at the SWD plant which has a salinity concentration of $680 \mathrm{~mol} / \mathrm{m}^{3}$ can produce electricity of $0.414 \mathrm{MW}$ $(3,636 \mathrm{MWh} / \mathrm{y})$. If the electricity generated is used to substitute the electricity needs at the refinery plant, the $\mathrm{CO}_{2}$ emissions that can be mitigated is $2,955,915 \mathrm{kgCO}_{2} / \mathrm{y}$.
\end{abstract}

Keywords : $\mathrm{CO}_{2}$ emission, sea water desalination, reverse electrodialysis

suka.budi@esdm.go.id

\section{Introduction}

Climate change occupies the highest position as a cause of global disasters such as natural disasters, extreme weather, food and clean water crises, loss of biodiversity, and collapse of ecosystems. [1]. The biggest cause of climate change is an increase in the earth's surface temperature (global warming) which occurs due to increased concentrations of greenhouse gases (GHG) [2]. The source of global GHG emissions based on the type of GHG gas, the largest order comes from $\mathrm{CO}_{2}$ emissions (76\%), then followed by $\mathrm{CH}_{4}(16 \%)$ and $\mathrm{N}_{2} \mathrm{O}(6 \%)$ [3]. Meanwhile, by economic sector (including land use change), the largest contributors to GHG emissions are electricity and heat production (25\%), agriculture and other land use (24\%), industry (21\%), transportation (14\%), other energy $(10 \%)$ and buildings (6\%) [3]. In fact, the technological advances that we enjoy today are built on the use of fossil fuels such as electricity and transportation which produce 
a lot of GHG emissions, especially $\mathrm{CO}_{2}$. Therefore, an increase in the effect of greenhouse gases cannot be avoided and disasters due to climate change are starting to arrive. To avoid the dangers caused by climate change is to reduce the production of $\mathrm{CO}_{2}$ emissions by diverting the use of fossil energy with renewable energy.

Reverse electrodialysis (RED) is a form of renewable energy source that is environmentally friendly because it does not produce $\mathrm{CO}_{2}$ emissions and does not use moving parts so that its production will last forever [4]. RED converts the free energy Gibbs from the difference in salinity of two solutions [5]. The working principle of RED is shown in Figure 1. RED is a development of ion exchange membrane (IEM) technology. The membrane on RED is arranged alternately between the cation exchange membrane (CEM) and the anion exchange membrane (AEM). The alternating solutions of different salinities are flowed in the space between the membranes (compartments).

RED has an electrode sys-tem consisting of anode, cathode and elec-trode rinse solution (ERS). The anode and cathode are located at the end of the stack and are equipped with a current collector for tap-ping the electric current to the load. The elec-trode rinse solution (ERS) functions as an ion rinse on the electrode, which flows from the anode to the cathode [5] [6].

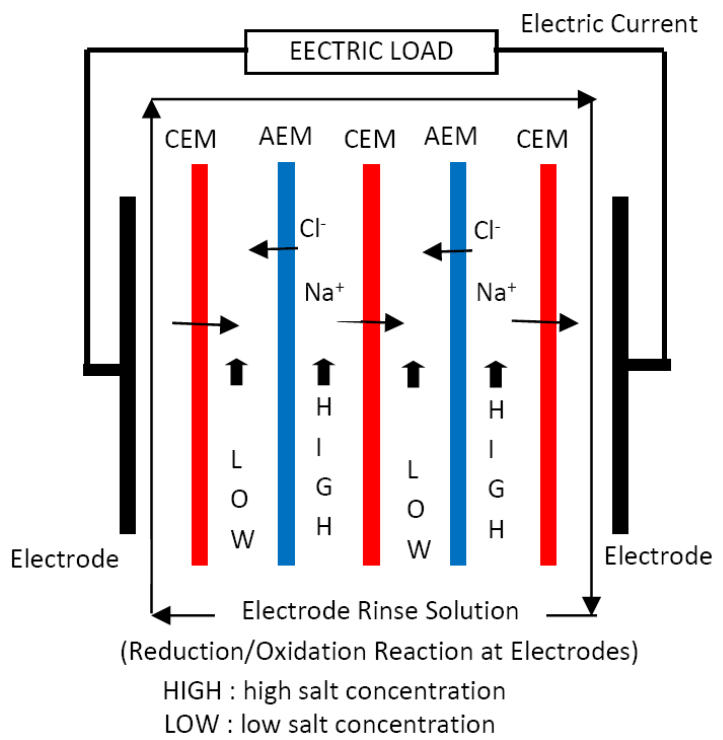

Figure 1. RED Stack Schematic (2 cells)
Meanwhile, many industries in Indonesia that are built on the coast have difficulty in supplying water to operate the plant. To solve the problem, they build a water treatment unit that processes sea water into industrial water or fresh water, this unit is called sea water desalination (SWD). In this process, many technologies are used and the common one is using distillation technology. SWD with distillation technology is an SDW unit that is energy-intensive and has low efficiency, 95\% of the seawater as SWD feed becomes blowdown water which is returned to the sea. Because SWD blowdown water has a high enough salinity level, the blowdown water can be converted into electrical energy through RED technology.

With the above background, this article presents an analysis of the use of RED technology on SWD as an effort to mitigate the production of $\mathrm{CO}_{2}$ emissions.

\section{Materials and methods}

To analyze the $\mathrm{CO}_{2}$ emission mitigation at SWD, data is needed which is obtained from the results of reading the operating conditions at an oil refinery in Indonesia that is built near the coast. SWD data includes sea water flowrate, flowrate of water product, energy consumption in the form of electrical energy to run the pump and steam energy to evaporate sea water in the distillation process.

Because SWD energy needs are met from combined heat and power (CHP), data on CHG operating conditions are required including fuel data used, namely residual fuel oil (RFO) flowrate, liquid petroleum gas (LPG) flowrate, electricity product (current, voltage, cos phi), steam product (flowrate, pressure, temperature). To calculate the electric power and steam power from the data obtained, the following equation is used

$P_{e l}=\sqrt{3} \cdot I \cdot V \cdot \operatorname{Cos} \theta$

$H=M_{\text {Steam }} \cdot$ Enthalpi

with $P_{e l}$ : electric power (W), I: electric current (Ampere), $V$ : electric voltage (volt), $\theta$ $:$ phase angel between electric voltage and 
current (rad), $H$ : steam energy (J), $M_{\text {Steam }}$ : mass of steam (kg), Enthalpi : enthalpy of steam $(\mathrm{J} / \mathrm{Kg})$.

To calculate the amount of $\mathrm{CO}_{2}$ emission mitigation in SWD, it begins with calculating the total of $\mathrm{CO}_{2}$ emission generated by $\mathrm{CHG}$ followed by calculating fractional $\mathrm{CO}_{2}$ emissions. The fractional $\mathrm{CO}_{2}$ emissions are from electricity products and steam products. The $\mathrm{CO}_{2}$ emission factors for the electricity product is obtained by dividing the fractional $\mathrm{CO}_{2}$ emissions of electricity product by the total electricity product. The $\mathrm{CO}_{2}$ emissions factor for steam product is obtained by dividing the fractional $\mathrm{CO}_{2}$ emissions for steam product with the total steam product. Electric product and steam product $\mathrm{CO}_{2}$ emission factors are used to calculate the $\mathrm{CO}_{2}$ emission in SWD and the amount of $\mathrm{CO}_{2}$ emission mitigation in SWD with RED.

The total of $\mathrm{CO}_{2}$ emissions in $\mathrm{CHG}$ can be calculated using the emission factor on a stationary engine using the IPCC Tier-1 table with the following equation

$$
E_{T}=F_{\text {Fuel }} \cdot L H V_{\text {Fuel }} \cdot E_{F}
$$

with $E_{T}$ : total of $\mathrm{CO}_{2}$ emission $\left(\mathrm{kgCO}_{2}\right), F_{\text {Fuel }}$ : mass of fuel (kg), $L H V_{\text {Fuel }}$ : low heating value of fuel (TJ $/ \mathrm{kg}), E_{F}$ : emission factor of stationer engine (as IPCC Tier-1) $\left(\mathrm{kgCO}_{2} / \mathrm{TJ}\right)$ The $\mathrm{CO}_{2}$ emission fraction is calculated using the following equation

$$
\begin{aligned}
& E_{H}=\frac{H / e_{H}}{H / e_{H}{ }^{P}{ }^{P l} / e_{P}} \cdot E_{T} \\
& E_{T}=E_{P}+E_{H}
\end{aligned}
$$

with $E_{H}: \mathrm{CO}_{2}$ emission of steam product $\left(\mathrm{kgCO}_{2}\right), \mathrm{H}$ : power output of steam product (MW), $e_{H}$ : efficiency of steam product, $P_{e l}$ : power output of electric product (MW), $e_{P}$ : efficiency of electric product, $E_{T}$ : total of $\mathrm{CO}_{2}$ emission $\left(\mathrm{kgCO}_{2}\right), E_{p}: \mathrm{CO}_{2}$ emission of electric product $\left(\mathrm{kgCO}_{2}\right)$.

In this article, the efficiency of the electric product fraction is $35 \%$ (US Standard) and for product steam fraction is $80 \%$ (US Standard) [7]. $\mathrm{CO}_{2}$ emission factors for electric products and steam products are using the following equation
$E_{\text {COZEl }}=E_{P} / W_{e l}$

$E_{\text {cozst }}=E_{H} / W_{s t}$

with $E_{C O 2 E l}: \mathrm{CO}_{2}$ emission factor of electric product (tonCO ${ }_{2} / \mathrm{MWh}$ ), $E_{\text {Cozst }}: \mathrm{CO}_{2}$ emission factor of steam product (tonCO $2 / \mathrm{MWh}), W_{e l}$ : the electric energy of CHP product (MWh/y), $W_{s t}$ : the steam energy of CHP product $(\mathrm{MWh} / \mathrm{y}), E_{H}: \mathrm{CO}_{2}$ emission of steam product (tonCO $2 / y$ ), $E_{p}: \mathrm{CO}_{2}$ emission of electric product (tonCO $2 / \mathrm{y}$ ).

To determine the amount of $\mathrm{CO}_{2}$ emission mitigation on SWD using RED, the number of Gibbs free energy from blowdown water must be known first. To determine the Gibbs free energy from blowdown water, it is assumed that the blowdown water which has a concentration of $0.616 \mathrm{~mol} / \mathrm{L}$ as a concentrated solution and river water which is brackish water with a concentration of 0.1 $\mathrm{mol} / \mathrm{L}$ as a dilute solution and flowrate of blowdown water and river water considered equal [8].

The number of Gibbs free energy is calculated by the following equation [9]

$$
\begin{aligned}
& \Delta G=2 R T\left[V_{L} C_{L} \ln \frac{C_{L}}{C_{M}}+V_{H} C_{H} \ln \frac{C_{H}}{C_{M}}\right](8) \\
& C_{M}=\frac{V_{L} C_{L}+V_{H} C_{H}}{V_{L}+V_{H}}
\end{aligned}
$$

with $\Delta G$ : free energy Gibbs/s (W), R: gas constants $\left(8,31 \mathrm{~J} / \mathrm{mol} .{ }^{\circ} \mathrm{K}\right), V_{L}$ : dilute flowrate $\left(\mathrm{m}^{3} / \mathrm{s}\right), \quad \mathrm{T}$ : temperature $\left({ }^{\circ} \mathrm{K}\right), C_{L}$ : dilute concentration $\left.\left(\mathrm{mol} / \mathrm{m}^{3}\right),\right), V_{L}$ : concentrate flowrate $\quad\left(\mathrm{m}^{3} / \mathrm{s}\right), \quad C_{L}: \quad$ concentrate concentration $\quad\left(\mathrm{mol} / \mathrm{m}^{3}\right), C_{M}: \quad \operatorname{mix}$ concentration $\left(\mathrm{mol} / \mathrm{m}^{3}\right)$.

To get the amount of $\mathrm{CO}_{2}$ emission that can be mitigated is to multiply the electrical energy generated by RED with the $\mathrm{CO}_{2}$ emission factor of the electric product generated by CHP. While the electrical energy generated by RED is obtained by multiplying the potential Gibbs energy from mixing two solutions with the generating efficiency of RED. In this article, the RED generator efficiency used is $45.7 \%[10]$. 


\section{Results and Discussion}

Sea water desalination (SWD) is a unit that processes sea water into industrial water, clean water and even drinking water. In this article, SWD analysis is used as a unit to supply industrial water for oil processing purposes. There are 8 SWD units, 7 SWD units are operated with a total production of 242 $\mathrm{m}^{3} / \mathrm{h}$ with sea water as raw material with a total flowrate of $3,403 \mathrm{~m}^{3} / \mathrm{h}$ (see Table 1 ). The technology used is multi-stage flash distillation technology with 24 stages [11], the working principle of seawater being pumped into the SWD unit and heated using steam which causes seawater to become steam which is then condensed to become industrial water. Not all seawater as SWD feed becomes steam, the remaining water in the SWD process is called blowdown water which is returned to the sea. The SWD with distillation technology is a SWD with very low efficiency, at this SWD, 93\% of the water is returned to the sea

To flow raw materials (sea water) to the SWD unit, 8 pumps are used with operating conditions as shown in table 1 , while for the distillation process, namely by evaporating seawater, steam is used with operating conditions as shown in table 1. It can calculate if the steam power consumption used is 64.1 MW or the annual steam energy consumption is $561,516 \mathrm{MWh} / \mathrm{y}$ and the electric power consumption to run the pump is $0.164 \mathrm{MW}$ or annual electric energy consumption is $1,436.64 \mathrm{MWh} / \mathrm{y}$. The total power used is $64,264 \mathrm{MW}$ or the total annual energy consumption is $562,952,640 \mathrm{MWh} / \mathrm{y}$.

Table 1. Operating point of SWD in oil refinery

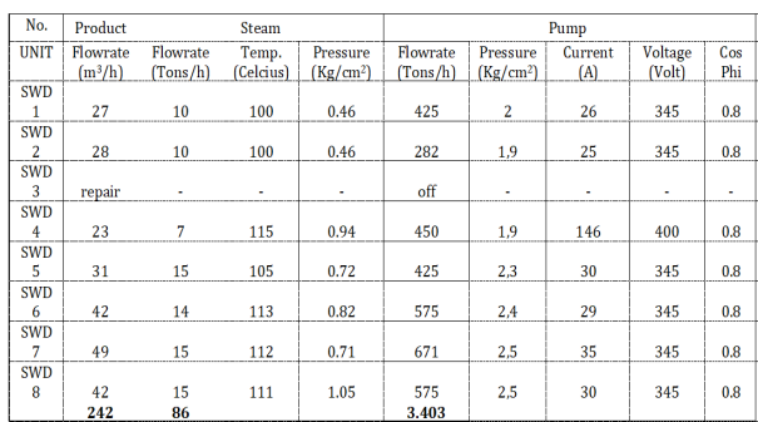

Tabel 2. Capacity and operation condition of Boiler CHP Units

\begin{tabular}{|c|c|c|c|c|c|c|}
\hline \multirow[b]{2}{*}{ CHP Units } & \multirow{2}{*}{$\begin{array}{l}\text { Boiler } \\
\text { Capacity } \\
\text { (tons/h) }\end{array}$} & \multicolumn{3}{|c|}{ HP Steam } & \multicolumn{2}{|c|}{ Fuel } \\
\hline & & $\begin{array}{l}\text { Flowrate } \\
\text { (tons } / \mathrm{h} \text { ) }\end{array}$ & $\begin{array}{l}\text { Pressure } \\
\left(\mathrm{kg} / \mathrm{cm}^{2}\right)\end{array}$ & $\begin{array}{l}\text { Temp } \\
\left({ }^{\circ} \mathrm{C}\right)\end{array}$ & $\begin{array}{l}\text { Fuel Oil } \\
\text { (tons } / \mathrm{h} \text { ) }\end{array}$ & $\begin{array}{l}\text { Fuel Gas } \\
\text { (tons/h) }\end{array}$ \\
\hline BLR1 & 60 & 46,0 & 62,6 & 462,7 & 1,8 & 0.83 \\
\hline BLR2 & 60 & 41,0 & 62,0 & 463,2 & 2,4 & 0,93 \\
\hline BLR3 & 60 & - & - & - & - & \\
\hline BLR4 & 110 & 69,4 & 60,9 & 459,2 & 5,6 & - \\
\hline BLR5 & 110 & 78,0 & 60,4 & 462,0 & 9,9 & 1,42 \\
\hline BLR6 & 110 & 77,0 & 60,3 & 465,0 & 8,5 & 1,32 \\
\hline BLR7 & 110 & 77,5 & 60,7 & 461,3 & 9,6 & 0,57 \\
\hline BLR8 & 110 & 75,5 & 60,4 & 464,0 & 7,1 & 0,94 \\
\hline Total & 730 & 464,4 & 60,9 & 462,5 & 44,9 & 6,01 \\
\hline
\end{tabular}

Tabel 3. Capacity and operation condition of Steam Turbine Generator CHP Units

\begin{tabular}{|c|c|c|c|c|c|c|c|}
\hline \multirow{2}{*}{$\begin{array}{c}\text { Generator } \\
\text { Units }\end{array}$} & \multirow{3}{*}{$\begin{array}{c}\text { Capacity } \\
\text { MW }\end{array}$} & \multicolumn{3}{|c|}{ Electricity } & \multicolumn{3}{|c|}{ MP Steam } \\
\hline & & $\begin{array}{c}\text { Voltage } \\
\text { (volt) }\end{array}$ & $\begin{array}{c}\text { Current } \\
\text { (ampere) }\end{array}$ & $\begin{array}{l}\text { Cos } \\
\text { Phi }\end{array}$ & $\begin{array}{l}\text { Flowrate } \\
\text { (tons/h) }\end{array}$ & $\begin{array}{l}\text { Pressure } \\
\left(\mathrm{kg} / \mathrm{cm}^{2}\right)\end{array}$ & $\begin{array}{c}\text { Temp } \\
\left({ }^{\circ} \mathrm{C}\right)\end{array}$ \\
\hline STG1 & & 13800 & 235 & 0,83 & 43,9 & 18.7 & 370,9 \\
\hline STG2 & 8 & 13800 & 245 & 0,82 & 49.9 & 18.8 & 371,9 \\
\hline STG3 & 8 & - & - & $\cdot$ & - & $\cdot$ & - \\
\hline STG4 & 20 & 13800 & 600 & 0,85 & 70,0 & 18.7 & 360,0 \\
\hline STG5 & 20 & 13800 & 400 & 0,86 & 56,0 & 18.5 & 345,5 \\
\hline STG6 & 20 & 13800 & 410 & 0,82 & 61,0 & 18.8 & 350,2 \\
\hline STG7 & 20 & 13800 & 405 & 0,85 & 45,0 & 18.5 & 352,0 \\
\hline STG8 & 8 & 13800 & 240 & 0,80 & 36,0 & 18.5 & 348,2 \\
\hline Total & 112 & & & & 361,8 & 18,7 & 356,9 \\
\hline
\end{tabular}

If we calculate the energy required to produce $1 \mathrm{~m}^{3}$ of fresh water is $0.246 \mathrm{MWh} / \mathrm{m}^{3}$. It can be stated that this SWD unit is very wasteful of energy compared to the results of the Humplic et.all (30-90 kWh/m $\mathrm{m}^{3}$ [12]. For this reason, it is necessary to further investigate the cause of the energy leak in this plant.

There are 8 CHP system units with the total boiler capacity is 730 tons/h as shown in Table 2. From the table 2, it shows that the total HP steam product is 464.4 tons/h. The boiler system used fuel oil in the form of RFO (residue fuel oil) and fuel gas in the form of LPG. The total fuel oil consumed in this system is 44.9 tons/h and fuel gas is 6.01 tons/h. By using the LHV value are 39.46 $\mathrm{MJ} / \mathrm{kg}$ for RFO [13] and $45.5 \mathrm{MJ} / \mathrm{kg}$ for LPG [13], the energy consumption of the CHP system from fuel oil is $1,771,754 \mathrm{MJ} / \mathrm{h}$ $(15,520.57 \mathrm{TJ} / \mathrm{y})$ and from fuel gas is 273,455 $\mathrm{MJ} / \mathrm{h}(2,395 \mathrm{TJ} / \mathrm{y})$.

The total energy consumed is 2,045,209 MJ/h $(17,915.57 \mathrm{TJ} / \mathrm{y})$. This Boiler system is used to operate the steam turbine generator with a total capacity of $112 \mathrm{MW}$ (see Table 3). The steam turbine generates electricity with a total power of $50.7 \mathrm{MW}$ equivalent to 444,132 $\mathrm{MWh} / \mathrm{y}$ and MP steam 361.8 tons/h with an average pressure of $18.7 \mathrm{Kg} / \mathrm{cm}^{2}$ and an average temperature of $356.9^{\circ} \mathrm{C}$. 
The steam energy is equivalent with a power of $317 \mathrm{MW}(2,776,920 \mathrm{MWh} / \mathrm{y})$. By using IPCC Tier-1, the $\mathrm{CO}_{2}$ emission coefficients for stationary engines fueled are 77,400 $\mathrm{kgCO}_{2} / \mathrm{TJ}$ for RFO [14] and 63,100 $\mathrm{kgCO}_{2} / \mathrm{TJ}$ for LPG [14]. The $\mathrm{CO}_{2}$ emissions produced by the CHP system sourced from fuel oil is $137,133.76 \quad \mathrm{kgCO}_{2} / \mathrm{h} \quad(1,201,291,734$ $\mathrm{kgCO}_{2} / \mathrm{y}$ ) and those sourced from LPG are $17,255.01$ tonsCO $\mathrm{S}_{2} / \mathrm{h}\left(151,153,892 \mathrm{kgCO}_{2} / \mathrm{y}\right)$ and the total $\mathrm{CO}_{2}$ emission is $1,352,445,626$ $\mathrm{kgCO}_{2} / \mathrm{y}$. The $\mathrm{CO}_{2}$ emission fraction for electric product is $362.056 .594 \mathrm{kgCO}_{2} / \mathrm{y}$ and for steam product is $990.389 .032 \mathrm{kgCO}_{2} / \mathrm{y}$.

Thus, it is found that the $\mathrm{CO}_{2}$ emission factor of electric product in CHP system is 815.20 $\mathrm{kgCO}_{2} / \mathrm{MWh}$ and steam product is 262.22 $\mathrm{kgCO}_{2} / \mathrm{MWh}$. So that the $\mathrm{CO}_{2}$ emission in the SWD unit is obtained at $1,171,149 \mathrm{kgCO}_{2} / \mathrm{y}$ from electric consumption and 147,240,725 $\mathrm{kgCO}_{2} / \mathrm{y}$ from steam consumption. From both, the sum of total $\mathrm{CO} 2$ emission is $148,411,874 \mathrm{kgCO}_{2} / \mathrm{y}$.

The potential Gibbs energy generated from the mixing of SWD unit blowdown water with river water or brackish water is obtained. It found that an electric power is $0.905 \mathrm{MW}$ or the energy equivalent is $7,928 \mathrm{MWh} / \mathrm{y}$. With RED, the Gibss energy can be captured to generated electric power of $0.414 \mathrm{MW}$ or the equivalent to electrical energy of 3,626 $\mathrm{MWh} / \mathrm{y}$. Therefore, the $\mathrm{CO}_{2}$ emission that can be mitigated is $2,955,915 \mathrm{kgCO}_{2} / \mathrm{y}$.

The results is very small compared to SWD unit which consumes very wasteful energy. If it is in accordance with the results of the review by Humplik et.all where for SWD with multi stage flash distillation (MSF), to produce industrial water as much as 242 $\mathrm{m}^{3} / \mathrm{h}$ or $2,119,920 \mathrm{~m}^{3} / \mathrm{y}$ requires energy of $63,597-190,792 \mathrm{MWh} / \mathrm{y}$ and produces $\mathrm{CO}_{2}$ emissions of $51,844,274$ - 155,533,638 $\mathrm{kgCO}_{2} / \mathrm{y}$. Due to the total emission generated by the SWD unit is only able to mitigate $\mathrm{CO} 2$ emissions around $1.9-5.7 \%$, it shows the result is very small.

More significant results can be obtained if SWD technology is replaced by reverse osmosis technology (SWRO = Sea Water Reverse Osmosis). The energy required to generate $1 \mathrm{~m}^{3}$ of industrial water at SWRO is around $2 \mathrm{kWh} / \mathrm{m}^{3}$ with efficiency is $50 \%$ [15]. To produce $242 \mathrm{~m}^{3} / \mathrm{h}\left(2,119,920 \mathrm{~m}^{3} / \mathrm{y}\right)$ of industrial water, the SWRO takes $484 \mathrm{~m}^{3} / \mathrm{h}$ $\left(4,239,840 \mathrm{~m}^{3} / \mathrm{y}\right)$ of sea water and the energy of 4,239.8 MWh/y. The SWRO also produced blowdown water of $242 \mathrm{~m}^{3} / \mathrm{h}(2,119,920$ $\mathrm{m}^{3} / \mathrm{y}$ ) with a salinity concentration of $68 \mathrm{~g} / \mathrm{L}$ (assuming $35 \mathrm{~g} / \mathrm{L}$ seawater and $1 \mathrm{~g} / \mathrm{L}$ fresh water $=0.5 \mathrm{~g} / 0.5 \mathrm{~L}$, the blowdown water is $34.5 \mathrm{~g} / 0.5 \mathrm{~L}=69 \mathrm{~g} / \mathrm{L}(\mathrm{NaCl})=1.18 \mathrm{~mol} / \mathrm{L}=$ $\left.1,180 \mathrm{~mol} / \mathrm{m}^{3}\right) \cdot \mathrm{CO}_{2}$ emission produced by this system is $3,456,285 \mathrm{kgCO}_{2} / \mathrm{y}$.

If SWRO blowdown water is converted into electrical energy with RED, it will produce an electric power of $719,6 \mathrm{MWh} / \mathrm{y}$ and $\mathrm{CO}_{2}$ emissions that can be mitigated is 586,618 $\mathrm{kgCO}_{2} / \mathrm{y}$. This value is equivalent to $17 \%$ of the $\mathrm{CO}_{2}$ emissions generated by the SWRO system to produce $242 \mathrm{~m}^{3} / \mathrm{h}$ of industrial water.

\section{Conclusion}

Analysis has been carried out to determine the amount of $\mathrm{CO}_{2}$ emissions that can be mitigated by utilizing RED on the SWD. SWD with multi-stage flash (MSF) technology in the unit used as a case study using wasteful energy consumption and resulting in insignificant mitigation of $\mathrm{CO}_{2}$ emissions, is therefore suggested to investigate further to look for energy leaks. Mitigation of $\mathrm{CO}_{2}$ emissions with RED will appear more significant if the SWD technology used is SWRO technology. To increase the amount of $\mathrm{CO}_{2}$ emission mitigation it is recommended to use SWRO technology to process seawater into industrial water and combine SWRO technology with RED technology for better energy utilization and save the environment.

\section{Acknowledgements}

We would like to express our appreciation to the Ministry of Energy and Minerals Resources Republic of Indonesia for the funding of this research, Polytechnic of Energy and Minerals (PEM Akamigas), Diponegoro University for IT facilities for this research. 


\section{References}

[1] B. Brende, "The Global Risks Report 2019 14th Edition," World Economic Forum, Cologny/Geneva Switzerland, 2019.

[2] M. Denchak, "The lowdown on the earth's central environmental threat," 23 February 2017. [Online]. Available: https://www.nrdc.org/stories/global -climate-change-what-you-needknow.

[3] IPCC, "AR5 Climate Change 2014: Mitigation of Climate Change," Cambridge University Press, New York, USA, 2014.

[4] S. Handaja, H. Susanto and Hermawan, "Open Circuit Voltage Pada Reverse Electrodialysis Power Generation dengan Elektroda Carbon Microparticle," in National Conference of Industry Engineering and Technology, Semarang, Indonesia, 2020.

[5] J. Veerman, M. Saakes, S. Metz and G. J. Harmsen, "Electrical Power from Sea and River Water by Reverse Electrodialysis: A First Step from the Laboratory to a Real Power Plant," Environ. Sci. Technol, 44, p. 9207-9212, 2010.

[6] V. Castaño and S. Sáenz, "Design and optimization of a reverse electrodialysis stack for energy generation through salinity gradients," Revista DYNA, 84(202), ISSN 00127353, pp. 84-91, 2017.

[7] GHGProtocol, "Allocation of GHG Emissions from a Combined Heat and Power (CHP) Plant," A WRI/WBCSD GHG Protocol Initiative, 2006.

[8] H. Susanto, M. Fitrianingtyas, A. M. Samsudin and A. Syakur, "Experimental study of the natural organic matters effect on the power generation of reverse electrodialysis," International of Energy Research, p. DOI: 10.1002/er.3728, 2017.

[9] J. Veerman dan D. Vermaas, "Reverse Electrodialysis Fundamental," in Sustainable Energy from Salinity
Gradients, Cambrdge USA, Woodhead Publisher, 2012, pp. 77-133.

[10] S. Handaja, "Hasil Penelitian Disertasi "Pemanfaatan Limbah Baterai Sebagai Elektroda Nanoarticle Pada Reverse Electrodialysis Sebagai Pembangkit Listrik Ramah Lingkungan"," Universitas Diponegoro, Semarang Indonesia, 2021.

[11] Sasakura Engineering, "Operation and Maintenance Manual Book Volume I of 2160 m3/day Desalination Plant," Sasakura Engineering Co. Ltd., Osaka. Japan Energi, 1998.

[12] T. Humplik, J. Lee, S. C. O'Hern, B. A. Fellman, M. A. Baig, S. F. Hassan, M. A. Atieh, F. Rahman, T. Laoui, R. Karnik and E. N. Wang, "Nanostructured materials for water desalination," 2011.

[13] T. Engineering, "The Engineering ToolBox," 2001. [Online]. Available: https://www.engineeringtoolbox.com /fuels-higher-calorific-valuesd_169.html. [Accessed 3 December 2020].

[14] IPCC, "IPCC Guidelines for National Greenhouse Gas Inventories," 2006. [Online]. Available: https://www.ipccnggip.iges.or.jp/public/2006gl/vol2.h tml. [Accessed 3 December 2020].

[15] C. R. Bartels and K. Andes, "Consideration of energy savings in SWRO," Desalination and Water Treatment, vol. 51, pp. 717-725, DOI: 10.1080/19443994.2012.700038, 2012. 